\title{
Development of Cottage and Small-scale Industries in India
}

INDUSTRIAL development in India due to the wat is not confined to the large industries, such as textiles and iron and steel. The demand for the products of cottage and small-scale hand-loom industries has also increased; as a result of the experience gained in the supply of war orders, technical improvements are being made in these industries and steps are also being taken to organize the workers.

The Supply Department of the Government of India has found it useful to draw upon the smaller industries for the purpose of supplementing the mill supplies of blankets for the armed forces. The Government has approved grants for the benefit of cotton and small-scale woollen industries, for the hand-loom weaving industry, and for the sericultural industry. In the case of the sericultural industry, the grant will be used as previously for the production of seed free from disease and for research on silkworm diseases. As to the small-scale and cottage woollen industries, it was thought that the grant would be used most advantageously in procuring technical advice and assistance in respect of marketing arrangements. In previous years, such assistance had been employed for similar purposes, including the organization of co-operative societies. The Supply Department of the Government of India placed orders with the industry for $1,880,000$ blankets in 1941-2 and 2,847,300 blankets in 1942-3. (International Labour Review, October 1942, July 1943.)

\section{Wartime Industrial Developments in Africa}

IN examining the problem of industrial development in Africa it is necessary to take into account the effect of war requirements in forcing the pace of production in established local industries, in setting up new industries, and in improving means of communication and transport. In a recent broadcast Lord Swinton described the building of aerodromes and the servicing of aircraft in Nigeria and the Gambia, the development of railway and road transport, and the drive for increasing the production of foodstuffs and fats for export.

Brigadier W. H. A. Bishop, in The Crown Colonist, March 1943, in an account of wartime influences on British West Africa, describes the development of local timber resources to fill the urgent need for building material, the manufacturing locally of roofing shingles and tiles and the development of local textile, cement, soap and salt industries. In an article in the February number of the same Journal we read of the increased food production in the Gambia, and the November r941 number spoke of the production of foodstuffs and manufactured goods in Kenya for the Allied Armies in the Middle East.

These developments are bound to have a great effect on the future of Africa. The increased demand for foodstuffs has called for improvements in agricultural technique to which Mr. Stopford refers in his article. In the Gold Coast Africans with knowledge of agriculture have found employment with Europeans in a new branch of the Department of Agriculture, started in connexion with the food-production campaign; local breeders are being assisted by the authorities to increase the supplies of pigs, sheep, and fowls made necessary by the reduction of imports.

\section{Native Affairs Department of the Union of South Africa}

The Annual Review of the activities of the Union Department of Native Affairs gives some interesting news. The Department is concentrating on increased food production in Native areas in consequence of the wat situation. It has issued seeds and grain tanks to Native cultivators at so per cent. cost, and has increased its number of demonstration plots, and crop-growing competitions. It has also set up a number of Native markets in experimental areas.

The labour supply continues to cause anxiety. Farmers complain of shortage of labour 
as they have for some years past, but at the same time there has been a decline in the number of Natives employed in the gold-mining industry, with an increase in those employed in coal-mining, and mining for base metals. There seems also to be a decline in the figures for domestic employment, industry, and trade, although the statistics given in this Report are hardly adequate to give a true idea of the position. The official ban on recruiting of mine labour from the Northern territories is making the question of shortage of Native labour a more urgent one, and the Report, without suggesting any concrete remedies, concludes that the effect " seems to point to the need for consideration being given to the methods which practice and custom have established for making use of the country's labour force, and for encouragement being given to Labour itself to undertake work in a more regular and stable manner than has been the case hitherto'.

The publication of the Report of the Interdepartmental Committee on the Social, Health, and Economic Conditions of Urban Natives in the Union receives comment, and it may well prove an important event in the history of Municipal Native Affairs Departments. Other items of news on the welfare side are the beginning of milk feeding in Native Schools. By the Binfield Milk Scheme of Victoria East 1,200 children are receiving a pint of milk a day, and other schools are evidently following suit. The decision in the Transkeian territories to provide training for Native women as community workers or home demonstrators is also of interest.

\section{Institut Francais d'Afrique Noire}

IT is with great satisfaction that we record the arrival from Dakar of five numbers of Notes Africaines, a quarterly publication of the Institut Français d'Afrique Noire. It is indeed an encouraging sign of the times to be in touch once again with French West Africa, and members will read with special pleasure and interest the article in this number of Africa by M. Monod.

Each issue of the Notes Africaines contains a number of short notes sent in by correspondents in A.O.F. on subjects of scientific interest that they have observed or about which they have obtained information. A great variety of subjects is treated: cases of human phosphorescence, market cries in Bambara, different methods of making fire, Pleistoscene finds, blacksmiths' customs, market prices, and so on. There are also some interesting notes on archaeological finds. And suggestions are made of subjects about which information would be welcome. The aim of the journal is clearly to stimulate interest and to encourage exact and methodical observation. There are many African as well as French names among the contributors.

Readers of Africa will be interested to know that, among other recent books listed, is one by Professor H. Labouret, Paysans d'Afrique Occidentale (Paris, 1941, pp. 307). It is described as 'dorénavant l'un des premiers ouvrages à lire sur l'A.O.F.'

\section{Labour Conditions in the Belgian Congo}

REgulations governing the employment of indigenous people in the Belgian Congo have been collected in a volume entitled Main-d'auwre indigène: Réglementation des Contrats de Travail (Congo Belge: A.I.M.O./ENS 1942). The first part of this volume consists of ordinances and decrees governing labour conditions in the Belgian Congo as a whole. The most comprehensive is the ordinance of December, 1940, providing for the health and safety of workers, and regulating labour contracts between Europeans and the indigenous people. In the second part of the volume are found the local measures adopted by the various provinces. These include details of rationing regulations, which will be of general comparative interest, and some information about special camps set up for the 'acclimatiza- 